\title{
Perspective Spiritual Intelligence QS. Luqman [31]: 12-19, Interpretation and Action
}

\author{
Aan Najib \\ Faculty of Tarbiyah and Teacher Training, Universitas Islam Negeri Sunan Ampel Surabaya, Indonesia \\ aan.najib@uinsby.ac.id
}

\begin{abstract}
Allah gives intelligence to every human being to understand all the ways of thinking and acting properly and correctly in developing his mindset so that he is able to develop and think clearly to weigh, decide and face things by focusing on the problems faced with brilliant solutions. Spiritual intelligence is still a little empirical research conducted on this type of intelligence. This research is a literature research with descriptive analysis method. This study found that there is a link between spiritual intelligence and a better social life. The form of spiritual intelligence in QS. Luqman [31]: 12-19 are as follows: Prohibition of shirk, belief in Allah's retribution, commandments of prayer, amar ma'ruf and nahi munkar, commands to be patient, prohibitions being arrogant and lowering one's voice.
\end{abstract}

Keywords

A-Quran; spiritual intelligence; Surah Luqman

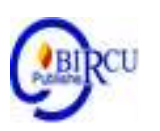

\section{Introduction}

Humans have stimulation and capture power that is very sensitive to education. Education that must be experienced and carried out by humans is education that lasts a lifetime, so the learning process for someone can continue and is not limited to the world of school (Fahmi, 2013). The essence of Islamic religious education lies in its ability to develop children's potential to become faithful and pious human beings and can appear as khalifatullah fi al-ardh (Akhirin, 2013; Hanafi, 2016). This essence becomes a reference to learning methods to achieve maximum goals.

The term "Islam" in education shows that education is education that contains an Islamic style, so that all components contained in educational activities are based on Islamic teachings (Abdullah, 1995; Kurniawan \& Syakur, 2017; Muttaqiyathun, 2012). Then what is the meaning of education in the view of Islam itself? before answering these questions we must first know what the meaning of education according to education experts. Education is an activity to develop all aspects of human personality that last a lifetime. Education is essentially the development of human potential or abilities as a whole, which is implemented by teaching various knowledge and skills needed by humans themselves. Education is a conscious guidance or leadership by educators of the physical and spiritual development of students towards the formation of the main personality (Naim, 2014).

The definition above has shown that education is a way to educate a person in order to achieve certain goals in education itself. Likewise with education according to Islam, namely guidance given to others in order to develop according to the basics of Islamic teachings. Because in Islamic education there are directions that indicate the improvement of mental attitudes and behavior in accordance with Islamic teachings, both for oneself and for others (Rahmawati, 2016). From this it can be explained that education in Islam is the guidance of an educator for students according to Islamic teachings to become a complete 
Muslim.

In the world of education, educators must have good character, because the educator is an advisor to their students. With a noble character, under any circumstances, educators must have self-confidence, istiqomah and immovable (Irfani, 2017). The educator personality which is based on noble morals certainly does not grow by itself, but it requires serious effort, hard work, tirelessly and with the intention of worship. To become a role model for their students, of course, personal and what an educator does will get the spotlight from their students and those around them who think or recognize them as educators.

Educators who are polite, respect their students, are honest, sincere and can be emulated, have a significant effect on success in education. An educator should be able to be a role model for students and a community like the Prophet to be a good role model. As explained in al-Qur'an surah al-Ahzab [33] verse 21, namely:

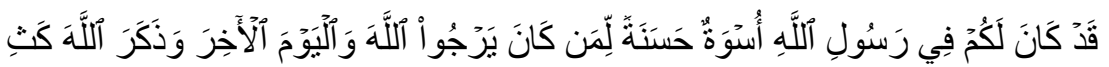

"Indeed, the Prophet (himself) is a good role model for you (namely) for those who hope for (the mercy) of Allah and (the arrival of) the Day of Resurrection and chant a lot of Allah".

The personality of the educator is very beneficial for the growth and development of the morals of the students, and can foster the personal intelligence of these students. This is important because in line big, the duty and responsibility of an educator is to develop the intelligence that is in each of his students (Said \& Rahmawati, 2018). This intelligence must be developed so that students can grow and grow up to become intelligent humans and are ready to face all challenges in the future. Among the intelligences that need to be developed by an educator are as follows:

1). Intellectual intelligence, 2) Emotional intelligence, 3). Spiritual intelligence.

An educator should communicate politely. As explained in al-Qur'an surah an-Nahl [16] verse 125 , namely:

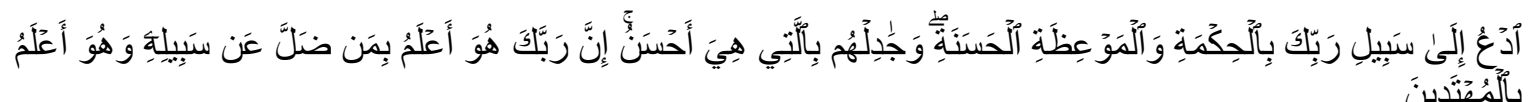

"Call (humans) to the way of your Lord with wisdom and good teaching and argue with them in a kind way. Indeed, it is your Lord who knows better about who has strayed from His ways and it is he who knows more about those who are guided".

An educator should apply the principle of true brotherhood and the spirit of togetherness, namely being open to each other to build brotherhood and cultivating a spirit of togetherness. This will affect the character of students, so that they will more easily accept and follow what the teacher says. As explained in al-Qur'an surah al-Hujurat [49] verse 10, namely:

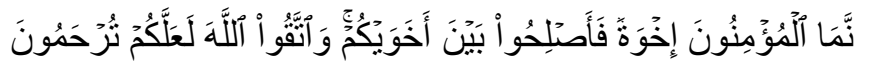

"Verily, the mu'min are brothers, therefore reconcile your two brothers and fear Allah so that you get mercy". 


\section{Review of Literature}

\subsection{Purpose of Islamic Education}

Education is a system and a process that involves various components. In formulating goals, there are several principles that must be considered (Fauzi, 2015). These principles are as follows:

1. Universal principles, namely principles that view all aspects of religion (aqidah, moral worship and muamalah), humans (physical, spiritual, and nafsani), society and the order of life, as well as the existence of the universe and life.

2. The principle of balance and simplicity, a balance between various aspects of life and needs.

3. The principle of clarity, the principle in which there are teachings and laws that provide clarity to the human psyche.

4. The principle of not contradicting, between components and other components is not contradicting so that it supports each other.

5. The principle of realism and can be implemented.

6. The principle of desired change.

7. The principle of safeguarding individual differences.

8. Dynamic principles in changes and developments that occur in education actors, as well as the environment in which education is carried out.

One thing that wants to be realized in the educational process is the crystallization of various personal values of students. That is called the end goal. The final goal must be complete, covering all aspects, and integrated in a round and whole edial personality pattern. The final goal contains Islamic values in all its aspects, namely normative aspects, functional aspects, and operational aspects (Abdullah, 1995; Fauzi, 2015). Thus it is clear that the goal of Islamic education is to achieve a balance in the growth of human personality (students) in a comprehensive and balanced manner which is carried out through training of the soul, mind (intellect), professional human self and senses to make it a human being who has a kaffah area to be able to carry out his duties. Duty of servitude and caliphate on this earth.

\subsection{The Story in the Al-Qur'an}

The story in the Al-Qur'an is a true story (true story), has many meanings and a very high series of storylines, but even with the high literary value of the stories in the Qur'an it does not make the story difficult to understand (Irfani, 2017; Syakur, 2017). However, the story is very easy for everyone to digest and can be enjoyed by all groups. The stories in the Al-Qur'an have a high enough urgency for children, especially stories that have tawhid and morality values that will be able to bring children closer to their natural values, and develop them properly, mental and spiritual development of children, which will become characters children later when they are adults in determining their life (Naim, 2014; Widodo \& Ilmiyah, 2019).

The exemplary stories in the Qur'an are excellent examples for all generations to follow, and are a fitting reflection for receive serious attention for parents and educators to educating their students to be like what Islam aspires to be the generation of the kamil people (Naim, 2014; Suparlan, 2008). The educational paradigm in the Koran, namely education of sincere submission to Allah SWT which leads to the achievement of happiness in the life of the world and the hereafter (Syakur, 2017; Yasbiati, Giyartini, \& Lutfiana, 2017). Education in the Koran is to foster humans individually and in groups, so that they are able to carry out their functions as servants of Allah Almighty and their Caliphs, in order to build this world in accordance with the concepts created by Allah SWT. 


\subsection{Kinds of Intelligence}

Intelligence is the added value of every human being in developing their mindset so that they are able to develop and think clearly to weigh, decide and face something by focusing on the problems faced with brilliant solutions (Akhirin, 2013; Hanafi, 2016). A person who is intelligent, the conversation he conveys will be structured and have value. When he speaks, what comes out are ideas, ideas, solutions, wisdom, knowledge and dhikr, so that the conversation is always useful (Daulay, 2015; Fahmi, 2013).

Intelligence is one of the great gifts from Allah swt to humans and makes it one of the advantages of humans compared to other creatures (Akhirin, 2013; Andriani, 2014; Irfani, 2017). Because with their intelligence, humans can continuously maintain and improve their increasingly complex quality of life, through continuous thinking and learning processes. Learning is assistance provided by educators so that the process of acquiring knowledge can be occured, mastery of proficiency and change, and the formation of attitudes (Buto, 2018).

Experience shows that a person's ability to overcome or solve adversity is determined by one's intelligence (Andriani, 2014). The smarter a person is, the easier it will be to overcome difficulties. So intelligence is a determining factor in the success or happiness of life. Likewise, the more intelligent a person is, the faster he will grasp all kinds of knowledge (Fauzi, 2015; Muttaqiyathun, 2012; Rafsanjani, 2017).

Talking about intelligence cannot be separated from involving the structure of reason in capturing something that is in touch with cognitive aspects, which later was found that intelligence is also related to the heart to foster affective aspects. Therefore, the intelligence of each person varies. So when talking about intelligence, at least will peel and pay more attention to IQ (intelligencequotion), IE (intelligence emitional), IS (spiritual intelligence), the three of which form the intellect that each individual has as a whole (Irfani, 2017; Muttaqiyathun, 2012). From here, we will explore the various kinds of human intelligence as follows:

\section{a. Intellectual Intelligence}

In a person there is an intelligence which is called intelligence Intellectual. This intelligence must be considered in Islamic religious education. In relation to this IQ, Islamic education is tasked with improving, developing, and cultivating the willingness, talents, interests, and intellectual abilities of students and giving them the knowledge and intelligence skills necessary in their life. Islamic education must be based on a comprehensive view of humans. Because the specialty of man is that he is a thinking or intelligent creature, then education has the duty and responsibility of encouraging humans to know and to understand.

Al-Qur'an it self discusses intelligence not based on logic and the ability to think logically, but as a gift or gift that comes from God who knows best and is addressed to someone who is intelligent. Then logical truth is also contained in it. In terms of intellectual intelligence, al-Qur'an implies that there is a measure of intelligence, as mentioned in the verse of the al-Qur'an, including one of which is the human ability to understand the law of causation. In understanding this law is based on QS. AL-Mukminun [23]: 80

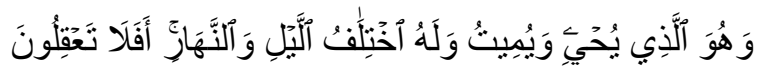

"And it is he who turns on and off, and it is he who regulates the exchange of night and day, so do you not understand".

This verse implies that in this life there is a law of cause and effect. This picture can be exemplified that behind life and death there are factors that cause, in other words, that intelligence is a gift which is inspired to every human being. 
Intellectual intelligence is intelligence that demands empowerment of the brain, heart, body, and activation of humans to interact functionally with others. And among the characteristics of intellectual intelligence, namely: a). Ability to observe quickly and carefully. b). Ability to hold orientation in space. c). Not much complaining or feeling inhibited d). Have high motivation e). Solve problems rationally. f). Not afraid to fail and always optimistic. g). Understand, predict and interpret.

\section{b. Emotional Intelligence}

Emotional intelligence that was first introduced by Goelman in 1995 known as Emotional Quation, by definition is the ability to know other people's feelings, the ability to motivate oneself, EQ also teaches and instills sympathy, love, motivation and the ability to respond to feelings of sadness or joy with fast. And EQ is the ability to see, observe, recognize and even question ourselves, is a basic requirement for using IQ potential effectively, in his book Working With Emotional Intelligence, where EQ consists of personal skills and social skills which refer to the ability to recognize our own feelings and the feelings of others, the ability to motivate oneself and the ability to manage emotions well in oneself and in relationships with others (Ichsan, 2016; Muttaqiyathun, 2012).

Therefore, people who have high emotional intelligence are shown their ability to control negative emotions, and their efforts to always bring out positive emotions and are characterized by the ability to control emotions when facing exciting realities (fun, sad, scary, annoying and so on). The ability to control emotions is called patience, or patience is the key to emotional intelligence (Naim, 2014; Pasek, 2017; Syakur \& Azis, 2020).

\section{c. Spiritual Intelligence}

Spiritual intelligence is an intelligence that involves the individual's mind and soul. This intelligence tends to arise from within the individual which returns to the individual's soul again. And spiritual intelligence is more of a concept related to how someone is intelligent in managing and utilizing the meanings, values, and qualities of their spiritual life which includes a more meaningful life (Akhirin, 2013; Syakur, Fanani, \& Ahmadi, 2020). According to Ary Ginanjar Agustian, spiritual intelligence is the ability to give meaning to worship for every behavior and activity, through steps and thoughts that are fitrah, towards a complete human being, and have a tauhidi mindset, and have the principle of "only because of Allah". A Muslim should not be lost in mere ritual worship, but must be able to make it a motivator and translate it into action, as Allah said. Al-Jum'ah [62]: 10

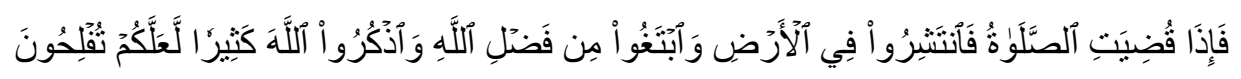

"When the prayers have been fulfilled, then you will be scattered on the face of the earth and seek Allah's grace and remember Allah a lot so that you will be lucky".

From a psychological point of view, it is not certain that a person who is strong in worship and is devout in religion has good spiritual intelligence either, because spiritual intelligence does not limit humans to mere makhdloh (pure to Allah) worship, but how do they specialize with those around them (ghoiru makhdloh) namely intelligence that is able to give us the ability to differentiate, sense of morality, the ability to adjust rules coupled with understanding and love (Ichsan, 2016; Widodo, 2017). SQ is also an intelligence that gives us the equal ability to see when love and understanding are at their limit. Ability used to grapple with good and evil, to imagine unrealized possibilities for dreaming, aspiring and lifting oneself from humility.

Spiritual intelligence tends to encourage us to always look for innovation to produce something more than what is currently achieved, spiritual intelligence will encourage us to 
think and see life from various sides (Rafsanjani, 2017; Wahidin, 2017). Not only thinking from one side only with the readiness of all parts of the brain and heart, spiritual intelligence is the base that the other intelligences are based on, where intelligence is interconnected and complementary. A spiritually intelligent person will show a sense of responsibility by being continuously oriented towards virtue, as Allah says in QS. Ali Imran [3]: 93

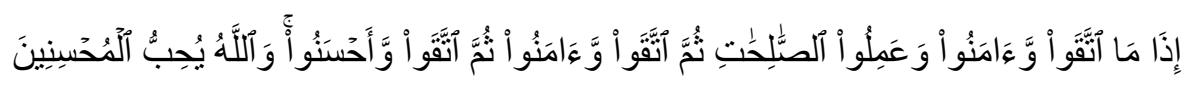

"If they always pious and have faith and do righteous deeds, then they remain responsible and have faith, then they are also responsible and do good. And Allah is pleased with those who do good deeds."

From the above verse it is very clear that taqwa, faith and good deeds are indications of spiritual intelligence. Spiritual intelligence is very closely related to how he maintains his principles and is responsible for carrying out the principles while maintaining balance and giving birth to beneficial values, giving meaning to worship for every behavior and activity, through steps and thoughts that are natural, towards a complete and possessing human being (Irfani, 2017; Naim, 2014; Syakur, 2015).

\section{Discussion}

\subsection{Characteristics of Spiritual Intelligence}

The characteristics of spiritual intelligence include the following:

1. There is a deep self-awareness, intuition and innate strength and authority that is possessed by hard work, efforts and God's help.

2. There is a broad view of the world by seeing oneself and the people around it are related.

3. Having noble values, consistent with what he talks about and being strong in his opinion.

4. Understand a high awareness of the purpose of life, so he will try to hang his dreams as high as the sky, by trying to do more than others do for more results.

5. Does not feel satisfied with what he gets, is always looking for new innovations, and usually tends to prioritize other people's affairs from his personal affairs or the desire to contribute to others.

6. Always have fresh, constructive and varied ideas. Active in everything, and often asks questions that have not been thought of by others before, giving rise to envy in others and a strong desire to imitate them.

7. There is a pragmatic and efficient view of reality, which often (but not always) produces healthy choices and practical results.

8. Avoid things that are deemed less necessary and even take up time just for something that is not useful. Usually people who have this spiritual intelligence tend to be alone outside of their activities, by filling the void with useful things, for example reading, and so on.

\subsection{Principles of Spiritual Intelligence}

Principles are profound and fundamental truths that serve as guidelines for behavior that have lasting and productive values (Irfani, 2017; Kurniawan \& Syakur, 2017; Mujib, 2015). Human principles clearly will not change, what changes is the way we understand and see these principles (Mujib, 2015). The more about correct principles the greater our personal freedom to act wisely. There are at least six principles that are implanted in spiritual intelligence, which relates to one's faith, which are as follows: 


\section{a. The Divine Principle}

All actions are only to Allah, do not expect strings attached and are done out of awareness. All work will be returned to the creator, who is the driving force, on the principle that no one can help except Allah.

\section{b. The Angel Principle}

Based on faith in angels, all tasks are carried out with discipline and in the best way according to the angel who is trusted by God to carry out all his commands. Where angels never stop complaining without any orders from Allah Himself, and do not expect rewards from their worship. Likewise human beings who will not stop to carry out their duties as servants of Allah and caliphs on earth whose task is to prosper parts of this earth without selfish consideration and selfishness.

\section{c. Leadership Principle}

Based on faith in the apostles. a leader must have firm principles, in order to be a true leader. Like Rasulullah SAW, a true leader who is respected by everyone. In addition to being a team member, the leader must be firm, responsible, respect superiors and love subordinates, be fair, convey trustworthiness and be wise. The true leadership character has been taught by the Prophet. If you reflect on history, that the leadership taught by the Prophet was a popular leader, taking part in every problem and something he was obliged to do with his own hands. This gives an image for the people to become responsible human beings. And in spiritual intelligence, responsibility is an important part. Everyone is a leader even though on the smallest scale, namely a leader for himself or on a large scale, all of them will be held accountable in the afterlife.

\section{d. Learning Principles}

Based on faith in the book. Likes to read and learn to increase knowledge and seek essential truths. Think critically about everything and use the Quran as a guide in action. because the Quran is a book of guidance that has always existed at all times. It is also evident that the Koran is the source of all knowledge, because there is no single knowledge that is not discussed in the Koran. Even though now we have many findings that come from non-Islamic or western sources, basically it cannot be separated from the teachings. That is in the Quran. It's just that Muslims are less competitive and lose fast in learning it, apart from scientists who have made many achievements in the Islamic world such as Ibn Sina, Ibn Rusy and so on. Lubis (2019) stated learning evaluation is seen as a separate part of learning activities, and is usually done after the learning activities are completed.

\section{e. The Principle of the Future (Visim Principle) at the Last Day}

Based on faith in the last day which is oriented towards life goals, both short term, medium term and long term. All because of the belief that there will be a day later when each individual will receive a reward for every action taken. Therefore, a person who has spiritual intelligence will feel that his life will be in vain without investing some of the results of his efforts towards others so that it is recorded as good deeds that deserve to be reckoned with and get rewarded, even though his basic orientation is only Allah alone. With the belief that there is life after death, they also believe that every practice in the world no matter how small it will be accounted for in the presence of Allah Almighty, the belief in immortality, makes them more careful in occupying life in this world, because they believe that this life is not once in this world alone, but there is a more essential life. The world is a place to plant, while the hereafter is a place to harvest. 


\section{f. The principles of regularity (Well Organized Principle) Qodlo 'and Qodar}

Based on faith in qodlo 'and qodar every success and failure, all is a destiny that has been determined by Allah. You should try earnestly and pray to Allah SWT. This principle teaches us how and no matter how hard we work with hope for more, in fact everything has been shared, but that does not mean giving up and surrender completely unconditionally. Both must be balanced between the affairs of this world and the hereafter, because no matter how we live in a world in general, everything must be endeavored.

\subsection{Various Forms of Spiritual Intelligence in QS. Luqman [31]: 12-19 \\ Various forms of spiritual intelligence in QS. Luqman [31]: 12-19 as follows:}

\section{a. The prohibition of curbing God}

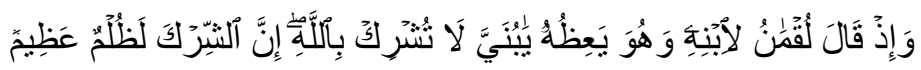

"And (remember) when Lukman said to his son, when he was teaching him a lesson:" $\mathrm{O}$ my son, do not associate (Allah) in fact associating partners with (Allah) is a great injustice ".

The advice given by Luqman to his son in verse 13 is wise advice, which is to teach his children a lesson in faith and show the truth and keep away from falsehood (Fauzi, 2019; Hudori, 2008; Syakur \& Azis, 2020). Associating something with Allah is making partners for Allah and this is the greatest sin of humans, shirk is an act that is strictly prohibited in religious teachings, because associating partners with Allah means acknowledging that there is someone other than Allah who can benefit and reject harm (Nadhiroh, 2013; Rahmawati, 2016). Shirk is a big tyranny because it puts something out of place and it is said to be a big sin, because it means equalizing Allah who has given all the blessings to another.

\section{b. Believe in the Hereafter}

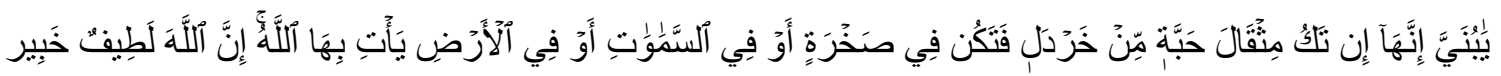

"O my son, verily if there is as heavy as a mustard seed, and is in the rock or the sky or in the earth, surely Allah will bring it. Allah is the most subtle, all-knowing. 29".

This $16^{\text {th }}$ verse explains Luqman's message to his son, this time it is the depth of Allah's knowledge. Allah is omniscient and knowledgeable. Human faith that is manifested in deeds is a source of improvement for him because God knows everything and is almighty over everything. And the deeds of humans while in the world will not be erased just like that, because Allah will definitely count them in the future (Muttaqiyathun, 2012; Syakur, 2017).

In fact, even if wrongdoing is as heavy as a mustard seed, Allah will undoubtedly repay it, Allah will present when the Day of Judgment will weigh the justice of charity and reward it, if it is good then it will be rewarded with kindness and vice versa.

\section{c. Commandments of Prayer}

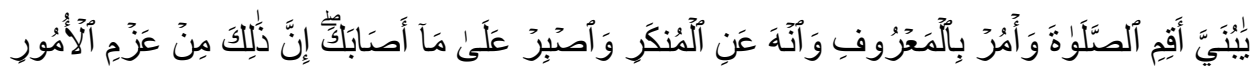

"O my son, pray and order to do that ma'ruf and prevent from evil and be patient with what happens to you. Indeed, this includes things that are required (by Allah)." 
Prayer is a form of worship that is composed of several words and deeds that begin with takbir, end with greetings, and fulfill various conditions and pillars (Fauzi, 2015, 2019). Establish prayers, that is, do your prayers perfectly in a way that is pleasing to you. Because in the prayer there is the pleasure of God, because the person who does it means facing and submitting to Him. And in prayer there is also another wisdom, which is to prevent evil and evil deeds. So when a person performs prayers perfectly, his soul will be clean from sin and submit to his Lord, both in joy and sorrow. Thus, verse 17 is Islamic education.

\section{d. Commandments of Kindness and Prohibiting Lawlessness}

"And order to do what is good and prevent from evil".

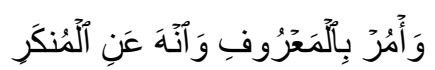

Luqman ordered his son to do good deeds and prevent himself from evil deeds, after he was good, proceed with preaching in the way of Allah by calling for good and prohibiting evil according to his ability (Rofiqoh \& Ansori, 2017). Amar ma'ruf is related to orders to people to do goodness optimally, as the key to success in life. Whereas nahi mungkar is a prohibition against people committing immoral acts against Allah which causes a life disaster and very painful torment in hell.

\section{e. Commandments for Patience}

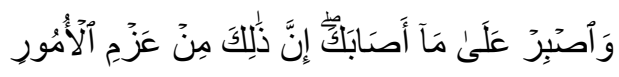

"And be patient with what befell you. Verily this includes things that are required (by Allah)."

Patience is by restraining oneself or limiting the soul from wanting to achieve something good or endure in the tightness and squeeze. Patience also means being fully willing to Allah's decrees. A Muslim must exercise his faith based on patience, because patience is half faith. Happy people who reap success are based on patience.

When disaster strikes in an effort to order the bad and prevent the evil, then be patient or not easily give up on the contrary, always be optimistic. Likewise to be patient with something that happens in living this life, Allah commands to be patient.

\section{f. Prohibition of Being Arrogant}

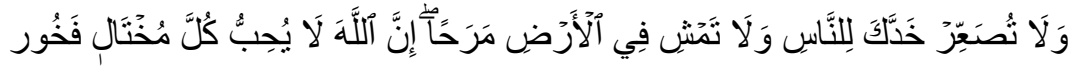

"And do not turn your face away from humans (because of being arrogant) and do not walk the face of the earth arrogantly. Surely Allah does not like those who are proud and proud".

In this $18^{\text {th }}$ verse, Luqman gives direction about character which is also considered important in fulfilling the obligations of amar ma'ruf nahi munkar so that his words are accepted by the community and affect them. Humans as social beings are required to get along well with others, because being good to God alone without being accompanied by kindness to others, including humility and concern for others is an inseparable series of servitude to God. Therefore, Luqman further advised his son not to be arrogant, arrogant and arrogant on the face of the earth, because Allah actually hates all these qualities (Fauzi, 2019; Pasek, 2017). Indicators of arrogance and pride in a person can be observed from their attitudes and behaviors. One of the calamities that arrogance hits is that it underestimates 
others. A person who is arrogant never tries to correct the trait that is proud of. One way to get rid of pride is to entrust the nature of judgment about good and bad qualities to others. And don't turn your face away from humans because of pride, but look to everyone with a radiant and humble face and if you step over, don't run hastily and also. don't be too lazy to spend time. It is forbidden to look away, and surly towards others because of pride and pride, because this is a despicable nature.

\section{g. Be Simple in Voicing}

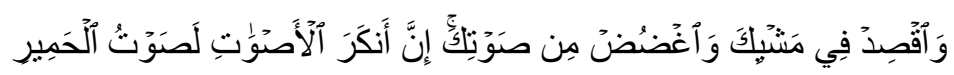

"And keep your feet simple and soften your voice. Verily, the worst of voices is the voice of a donkey."

Islam is a religion that regulates everything so that there are rules for running. Muslims should pay attention to their attitude, not only when walking but in all their actions. People who act simply and do not overdo it will not cause slander, and will not cause crime to anyone who wants it (Fauzi, 2019; Ichsan, 2016).

Then the next aspect is the ethics of speaking, namely not to exaggerate in speaking, do not speak aloud for things that are of no use as a form of ethics towards God and towards others, speaking softly reflects ethics and serenity (Fauzi, 2015; Hudori, 2008; Rafsanjani, 2017).

\section{Conclusion}

Humans in developing their mindset are always able to develop and think clearly to face, weigh, and decide something by centering on the problems faced with brilliant solutions. A person who is intelligent, the conversation he delivers will be structured and have value. When he talks, what comes out is ideas, ideas, solutions, wisdom, knowledge and dhikr, so that the conversation is always useful.

The form of spiritual intelligence in QS. Luqman [31]: 12-19 namely the prohibition of doing shirk, belief in the vengeance of Allah, the commandment of prayer, amar ma'ruf and nahi munkar, the command to be patient, the prohibition to be arrogant and lower one's voice. From Luqman's messages to his son, it can facilitate dialogue between mind and emotion, between soul and body. Because with his intelligence, humans can continuously maintain and improve the increasingly complex quality of life, through a process of thinking and learning continuously. Spiritual intelligence is the ability to give meaning to worship for every behavior and activity, through steps and thoughts that are fitrah, towards a complete human being, and have a tauhidi mindset, and have the principle of "only because of Allah"

\section{References}

Abdullah, A. (1995). Dimensi Epistemologis-Metodologis Pendidikan Islam. Jurnal Filsafat, $1(1), 9-18$.

Akhirin, A. (2013). Mengembangkan kecerdasan spiritual melalui rukun iman dan rukun Islam. Tarbawi: Jurnal Pendidikan Islam, 10(2).

Andriani, A. (2014). Kecerdasan Emosional (Emotional Quotient) dalam Peningkatan Prestasi Belajar. EDUKASI: Jurnal Pendidikan Islam, 2(1), 459â€“472-459â€“472. 
Buto, Z.A., and Hafifuddin. (2018). Learning Independence of Students at Dayah Muslim School in North Aceh. Budapest International Research and Critics Institute-Journal (BIRCI-Journal). 1(4): 224-231.

Daulay, N. (2015). Pendidikan karakter pada anak dalam pendekatan Islam dan Psikologi. MIQOT: Jurnal Ilmu-ilmu Keislaman, 39(1).

Fahmi, Z. (2013). Indikator pembelajaran aktif dalam konteks Pengimplementasian pendekatan pembelajaran aktif, kreatif, Efektif, dan menyenangkan (PAKEM). Al-Ta lim Journal, 20(1), 278-284.

Fauzi, A. (2015). Membangun Epistemologi Pendidikan Islam Melalui Kepemimpinan Spiritual: Suatu Telaah Diskursif. Empirisma: Jurnal Pemikiran dan Kebudayaan Islam, 24(2).

Fauzi, A. (2019). Aspek-Aspek Kecerdasan Spiritual dalam Konsep Pendidikan Luqman Hakim. Realita: Jurnal Penelitian dan Kebudayaan Islam, 17(1).

Hanafi, H. (2016). Kecerdasan Majemuk dan Metode Pembelajarannya. Jurnal Pendidikan Karakter JAWARA (Jujur, Adil, Wibawa, Amanah, Religius, Akuntabel), 2(1).

Hudori. (2008). Relasi Kecerdasan Spiritual Dan Pencarian Jejak Tuhan. Jurnal Soul, 1(2), 48.

Ichsan, M. (2016). Psikologi pendidikan dan ilmu mengajar. JURNAL EDUKASI: Jurnal Bimbingan Konseling, 2(1), 60-76.

Irfani, R. N. (2017). Formulasi Kajian Psikologis Tentang Teori-Teori Belajar dalam AlQuran dan Hadits. Ta'dib: Jurnal Pendidikan Islam, 6(1), 212-223.

Kurniawan, A., \& Syakur, A. (2017). The Correlation of Emotional Intelligence and Spiritual of Intelligence to Effectiveness Principals of Leadership. International Journal of Psychological and Brain Sciences, 2(1), 1-9.

Lubis, Z., et al. (2019). Learning Aqeedah Students who Learned with the Point Conterpoint Learning Model in Integrated Islamic Junior High School in Deli Serdang 2019-2020. Budapest International Research and Critics in Linguistics and Education (BirLE) Journal. 2(4): 514-524.

Mujib, A. (2015). Implementasi Psikospiritual dalam Pendidikan Islam. Madania: Jurnal Kajian Keislaman, 19(2).

Muttaqiyathun, A. (2012). Hubungan Emotional Quotient, Intelectual Quotient Dan Spiritual Quotient Dengan Entrepreneur's Performance Sebuah Studi Kasus Wirausaha. International Research Journal Of Business Studies, 2(3).

Nadhiroh, W. (2013). Memahami Narasi Kisah Al-Qur'an dengan Narrative Criticism: Studi atas Kajian AH John. Ilmu Ushuludin, 12(2), 213-238.

Naim, N. (2014). Kecerdasan Spiritual: Signifikansi dan Strategi Pengembangan. Ta'allum: Jurnal Pendidikan Islam, 2(1), 36-50.

Pasek, N. S. (2017). Pengaruh Kecerdasan Intelektual pada pemahaman akuntansi dengan kecerdasan emosi dan kecerdasan spiritual sebagai variabel pemoderasi. JIA (Jurnal Ilmiah Akuntansi), 1(1).

Rafsanjani, H. (2017). Kepemimpinan Spiritual (Spiritual Leadership). Jurnal Masharif alSyariah: Jurnal Ekonomi dan Perbankan Syariah, 2(1).

Rahmawati, U. (2016). Pengembangan kecerdasan spiritual santri: studi terhadap kegiatan keagamaan di rumah tahfizqu deresan putri yogyakarta. Jurnal Penelitian, 10(1), 97124.

Rofiqoh, A., \& Ansori, I. H. (2017). Kisah-Kisah (Qasas) dalam Al-Qur'an Perspektif I'jaz. Qof, 1(1), 25-37.

Said, A. N., \& Rahmawati, D. (2018). Pengaruh kecerdasan intelektual, kecerdasan emosional dan kecerdasan spiritual terhadap sikap etis mahasiswa akuntansi (studi 
empiris pada mahasiswa prodi akuntansi Universitas Negeri Yogyakarta). Nominal: Barometer Riset Akuntansi dan Manajemen, 7(1), 21-32.

Suparlan, S. (2008). Psikologi dan Kepribadian Perspektif Al-Quran. HUMANIKA, 8(1).

Syakur, A. (2015). Developing ESP Instructional Materials for Undergraduate Students of International Economic Departments in State Brawijaya University of Malang. Jurnal Edukasi, 1.

Syakur, A. (2017). Education For Sustainable Development (ESD) Sebagai Respon dari Isu Tantangan Global Melalui Pendidikan Berkarakter dan Berwawasan Lingkungan yang Diterapkan pada Sekolah Dasar, Sekolah Menengah dan Kejuruan di Kota Malang. Eduscience, 1(1), 37-47.

Syakur, A., \& Azis, R. (2020). Developing Reading Learning Model to Increase Reading Skill for Animal Husbandry Students in Higher Education. Britain International of Linguistics Arts and Education (BIoLAE) Journal, 2(1), 484-493.

Syakur, A., Fanani, Z., \& Ahmadi, R. (2020). The Effectiveness of Reading English Learning Process Based on Blended Learning through" Absyak" Website Media in Higher Education. Budapest International Research and Critics in Linguistics and Education (BirLE) Journal, 3(2), 763-772.

Wahidin, U. (2017). Pendidikan Karakter Bagi Remaja. Edukasi Islami: Jurnal Pendidikan Islam, 2(03).

Widodo, P. (2017). Peer Review Mengorganisasi Isi Pembelajaran Model Elaborasi Pada Mata Pelajaran Sosiologi SMA.

Widodo, P., \& Ilmiyah, M. (2019). The Implementation Freedom of Education in Extracurricular at Mutiara Ilmu Pandaan Elementary School. JournEEL, 1(1), 65-69.

Yasbiati, Y., Giyartini, R., \& Lutfiana, A. (2017). Upaya meningkatkan kecerdasan naturalis melalui kegiatan bercocok tanam di bambim Al-Abror kecamatan mangkubumi kota tasikmalaya. Jurnal PAUD agapedia, 1(2), 203-213. 